The SLCS series has been established as a companion series to STUDIES IN LANGUAGE, International Journal, sponsored by the Foundation "Foundations of Language".

Series Editors:
Werner Abraham University of Groningen The Netherlands
Michael Noonan University of Wisconsin-Milwaukee USA
Editorial Board:

Joan Bybee (University of New Mexico) Ulrike Claudi (University of Cologne)

Bernard Comrie (University of Southern California)

William Croft (University of Michigan) Östen Dahl (University of Stockholm)

Gerrit Dimmendaal (University of Leiden)

Martin Haspelmath (Free University of Berlin)

Ekkehard König (Free University of Berlin)

Christian Lehmann (University of Bielefeld)

Robert Longacre (University of Texas, Arlington)

Brian MacWhinney (Carnegie-Mellon University)

Marianne Mithun (University of California, Santa Barbara)

Edith Moravcsik (University of Wisconsin, Milwaukee)

Masayoshi Shibatani (Kobe University)

Russell Tomlin (University of Oregon)

John Verhaar (The Hague)

Volume 23

Bernard Comrie and Maria Polinsky (eds)

Causatives and Transitivity

\section{CAUSATIVES AND TRANSITIVITY}

Edited by

BERNARD COMRIE

MARIA POLINSKY

JOHN BENJAMINS PUBLISHING COMPANY AMSTERDAM/PHILADELPHIA 


\section{Table of Contents}

Preface

The inflectional category of voice: towards a more rigorous definition Igor A. Mel'čuk

\section{Library of Congress Cataloging in Publication Data}

Causatives and transitivity / edited by Bernard Comrie, Maria Polinsky.

p. cm. -- (Studies in language companion series, ISSN 0165-7763; v. 23)

Includes bibliographical references (p.) and index.

1. Causative (Linguistics) 2. Grammar, Comparative and general--Transitivity. I. Comrie, Bernard, 1947- . II. Polinsky, Maria. III. Series.

P292.C38 1993

$415-\mathrm{dc} 20$

ISBN 9027230269 (Eur.)/1-55619-375-0 (US) (alk. paper)

93-11698

๑ Copyright 1993 - John Benjamins B.V.

No part of this book may be reproduced in any form, by print, photoprint, microfilm, or any other means, without written permission from the publisher.

John Benjamins Publishing Co. P P.O. Box $75577 \cdot 1070$ AN Amsterdam · The Netherlands John Benjamins North America $\cdot 821$ Bethlehem Pike · Philadelphia, PA $19118 \cdot$ USA

Transitivity increase in Athabaskan languages Andrej A. Kibrik

Transitive and causative in the Slavic lexicon: evidence from Russian Johanna Nichols

More on the typology of inchoative/causative verb alternations Martin Haspelmath

The "second causative": a typological sketch Leonid I. Kulikov

"Make" and the semantic origins of causativity: a typological study Juan Carlos Moreno

Causatives and causality: towards a semantic typology of causal relations

Vera I. Podlesskaya

Causee and patient in the causative of transitive: coding conflict or doubling of grammatical relations? Isaac Kozinsky and Maria Polinsky

Bystander voice in English: a generalization masked in some versions of theta theory Catherine V. Chvany

Causative constructions in Svan: further evidence for role domination

Nina R. Sumbatova 


\title{
Through the looking-glass, and how causatives look there
}

\author{
Leonid I. Kulikov and Nina R. Sumbatova \\ Institute of Oriental Studies, Moscow
}

For V.P. Nedjalkov - on the occasion of his 65 th birthday

\section{Introduction}

A usually neglected approach to the typology of verbal categories is the investigation of their relations to other categories. Below we shall try to demonstrate that such an approach can contribute to a reanalysis or an extension of the inventory of categories. Analyzing the asymmetric structure of one of the categories, we have managed to find an interesting class of verbs which seems to fill a gap in the system of verbal categories. The present article deals with this candidate for a new category.

\section{Causatives and their asymmetric structure}

Nedjalkov and Sil'nickij (1969a: 6) defined causative situation (CS) as a complex situation which consists of two elementary situations $\left(\mathrm{S}_{\mathrm{i}}\right.$ and $\left.\mathrm{S}_{\mathrm{j}}\right)$ connected by the relationship of causation (causal copula $=$ CAUS), as shown in Fig. $I\left(V_{i}\right.$ and $V_{j}$ denote the main verbs of clauses corresponding to the situations $S_{i}$ and $\left.S_{j}\right)$ :

(I)

\section{$\mathrm{S}_{\mathrm{i}}$}

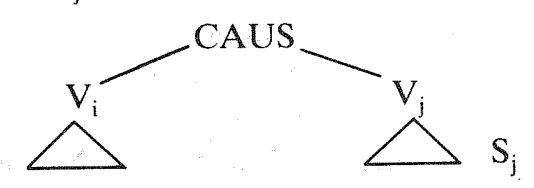

The symmetry of the CS (with regard to the vertical axis) is illusory. In causative sentences the clause denoting $\mathrm{S}_{\mathrm{i}}$ is often reduced: 
(1) We moved the date of the meeting because of John's illness.

$S_{i}$ CAUS

In (1) $S_{i}$ is "compressed" to an action nominal construction. The near reduction of $S_{i}$ to zero occurs when only a "trace" of the $S_{i}$ clause remains, namely, its principal argument. If $\mathrm{V}_{\mathrm{i}}$ is not relevant for the speaker, it may be left unspecified, leaving only the Causer:

(2) Peter caused us to return.

Compare Fig. (II) where the reduced clause is not shaded:

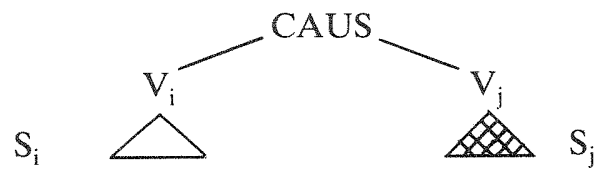

Many languages have regular devices for expressing a CS reduced in this way. When the causative copula is expressed by means of a separate verb (such as Germ. lassen, Fr. faire, Engl. make, have, etc.) we have an analytic causative; when it is expressed by a marker in the verb derived from $V_{j}\left(C A U S-V_{j}\right)$, which becomes the main verb of the clause union, thus dominating the first argument of $\mathrm{V}_{\mathrm{i}}$ (Causer), we have a morphological causative (cf. Nedjalkov and Sil'nickij 1969b: 25).

Hence, a language has morphological causatives if it has syntactic constructions in which the semantic representation follows the pattern in (I), under the following conditions:

(i) the meaning of $\mathrm{V}_{\mathrm{i}}$ is not specified (and, therefore, the corresponding clause is reduced);

(ii) the main verb of the clause union is CAUS- $V_{j}$, a verb derived from $V_{j}$ (the causative to $V_{j}$ ).

Thus, according to Fig. II and conditions (i-ii), if a causative situation is expressed by a causative construction (below abbreviated as CC), it is represented in an asymmetric way. This fact is well-known ${ }^{1}$ and can be easily accounted for, both from formal and common sense perspectives: a cause (reason) and a result are not equal. For the speaker and the listener, the result is usually more important than the cause, implying a sort of linguistic "discrimination" against the cause (cf. Nedjalkov and Sil'nickij 1969a: 7).

\section{Causatives and their looking-glass counterparts}

Theoretically, it may be assumed that a case opposite to the one just discussed is also possible; namely the cause can turn out to be more important for the speaker than the result. If such a situation were expressed in a language, we would get scheme (III), which is in fact a mirror reflection of (II):

(III)

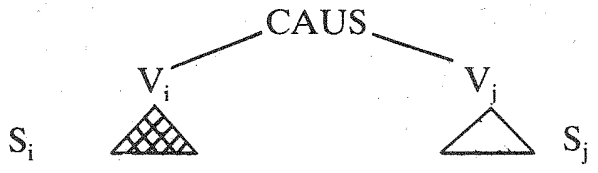

If we wish to apply this scheme to a natural language, conditions (i-ii) must be reformulated as follows:

(iii) the meaning of $\mathrm{V}_{\mathrm{j}}$ is not specified (and, therefore, the corresponding clause is reduced);

(iv) the main verb of the clause union is $V_{i}$-CAUS (derived from $V_{i}$ ).

As a matter of fact, these derived verbs ( $V_{i}$-CAUS) may be considered as a mirror reflection of causatives. The question arises as to whether constructions meeting conditions (iii-iv) are in fact attested in natural languages. Is there a language where we can find these "looking-glass causatives"? If so, how do they look there? Below we shall try to demonstrate that such a category can in fact be identified in at least one language.

We will begin by giving an example of a type of construction which meets only the last condition; this type is attested in the Andoke language of the Tupi-Guarani language family (see Landaburu 1979: 230). In Andoke, the verbal suffix - $k$ śséha signals that the main clause expresses a situation resulting from $S_{i}$ (in order to distinguish between this and an ordinary causative marker, we gloss it as CAUS'):

(3) ^-o-be-kấséha $b \wedge \quad-y i-i$ -I-eat-CAUS' I-sick-

'I ate ( $\mathrm{V}_{\mathrm{i}}$-CAUS) and [as a result] I became sick.'

However, here the $S_{j}$-clause is not reduced, and so this sentence may not be treated as a mirror reflection of a causative construction.

Next, we proceed to the analysis of constructions that meet conditions (iii-iv). We have identified such constructions in a less "exotic" language, namely in Russian.

Consider the following verbs, which are productively derived by means 
of the prefix do- and the suffix -sja (i.e. by means of the circumfix do-... - sja):

(4) rabotat' 'work' - dorabotat'sja (do obmoroka) 'work until fainting'

(5) podskazyvat' 'prompt' - dopodskazyvat'sja (do zamečanija učitelja) 'keep prompting (until the teacher's reprimand)', etc.

This derivational affix is very productive; in colloquial speech it may be combined with any imperfective verb denoting a conscious activity. This class of verbs is of course mentioned in Russian grammars and works on verbal derivation; ${ }^{2}$ also, a thorough analysis of this verbal class was recently presented by Mel'čuk (1987). Let us use X, Y to represent noun phrases, and $\mathrm{Z}$ to indicate a verb undergoing do-...-sja-derivation. Mel'čuk defines construction (6):

(6) X do-Z:PAST-sja do Y:GEN as follows: 3

(7) 'By excessively performing activity $Z, X$ underwent $Y$, so that $Y$ is unfavorable for $\mathrm{X}$.

This definition consists of three components which are relevant for the present study:

(a) $\mathrm{X}$ performs an activity $\mathrm{Z}$;

(b) performing $\mathrm{Z}$ by $\mathrm{X}$ implies a consequence $\mathrm{Y}$, i.e. $\mathrm{Z}$ causes $\mathrm{Y}$;

(c) $\mathrm{Y}$ is often not specified; 4 it is only known that $\mathrm{Y}$ is unfavorable for $\mathrm{X}$.

If we substitute $V_{i}$ and $V_{i}$ for $Z$ and $Y$, respectively, and omit the second part of the component (c), we get a formulation which meets requirements (iii-iv) exactly. Hence, the construction X do-Z:PAST-sja (without a Y argument) turns out to be almost an exact mirror reflection of typical causative constructions such as those described in (II), so that verbs like dorabotat'sja may be considered as counterparts of causatives in the Looking-Glass World.

Before we proceed to a more detailed analysis of these verbs, we need to find a term for this category. As was indicated above, the term "causative" is used for verbs following the pattern CAUS- $V_{j}$ where $V_{j}$ indicates a consequence having some (most commonly not expressed in the sentence) cause(s). In a parallel way, a verb $\mathrm{V}_{\mathrm{i}}$-CAUS containing the component $\mathrm{V}_{\mathrm{i}}$ which denotes a cause of some (commonly not expressed) event(s), i.e. a cause of some consequence(s) may be referred to as consecutive.

\section{On Russian consecutives}

4.1 Verbs in do-...-sja

A more detailed analysis of consecutives in do-...-sja would show that their parallelism to typical causatives is not quite perfect. Below we mention only some of the differences.

As has been mentioned, the causing event $S_{i}$ can remain absolutely unspecified. As for its counterpart (i.e. the resulting event $S_{j}$ ) in consecutive constructions (below abbreviated as $\mathrm{CsC}$ ), the speaker provides a little more information about it. In particular, a consecutive construction presupposes that the consequence(s) is/are undesirable for the main participant of $\mathrm{S}_{\mathrm{i}}$. This is true also for the situation when $\mathrm{Y}$ is omitted.

Another difference concerns the syntactic structure of the constructions under consideration. Thus, both causative and consecutive constructions are formed by creating a clause union from two (elementary) clauses. In the case of causatives, the most usual trace of the reduced clause is its main argument, i.e. the causer, which becomes the subject of the main predicate (i.e. causative). The underlying predicate $\left(V_{i}\right)$ is usually not expressed, although it can be represented, say, by a gerundial or absolute construction:

(8) I broke the window by throwing a ball into it.

By contrast, in a consecutive sentence the main participant of $S_{j}$ (if different from the agent of $S_{i}$, i.e. if $V_{j}$ is some conscious activity performed by somebody) remains most commonly unexpressed, whereas $V_{j}$ can be easily expressed by an action nominal construction (as in (9-10)) or a complement subordinate clause (as in (11-12)):

(9) Ja ležal na divane $s$ kakim-to glupym francuzskim romanom $i$ doležalsja do golovnoj boli.

(Garšin) 'I lay on the sofa with a silly French novel until I got a headache.'

(10) Prijateli dopilis' do bespamjatstva. 'Friends have drunk until they have lost consciousness.'

(11) Ja smotrel [na ee lico]... i dosmotrelsja do togo, čto tjagostnyje mysli načali brodit' $v$ moej golove.

(Družinin) 'I looked [at her face] so long that painful thoughts started crowding in my mind.' 
(12) Mamen'ka [...] doxozjajničalas', nakonec, do togo, čto, nakonec, rešitel'no ne znaet, čto delat'.

'Mother has kept house so zealously that she does not finally know what to do now.'

This observation demonstrates clearly that the degree of "discrimination" of the consequence in $\mathrm{CsC}$ does not reach the degree of "discrimination" of the cause in CC. 5

To conclude this section, we would like to touch upon one of the syntactic peculiarities of do-...-sja constructions. The case-marking pattern of verbs in do-... -sja is described by Mel'čuk (1987) in a rather detailed way (cf. also Rojzenzon 1959: 29-31); nevertheless, some corrections seem to be in order. In particular, the statement by Mel'cuk (1987: 637) that a verb in do-...-sja loses all the valencies (with the exception of the first one) of its non-derived counterpart $(Z)$ appears to be too categorical. These arguments do in fact show a tendency not to be expressed overtly, but still, if the consecutive verb dominates a noun phrase denoting a consequence (do $\mathrm{Y}: \mathrm{GEN}$ ), these valencies can be, in a way, restored:

(14) on zanimalsja matematikoj 'He did mathematics.'

(15) *on dozanimalsja matematikoj he:NOM do:CONS:PAST mathematics:INSTR

(15) is ungrammatical because of the instrumental NP; only on dozanimalsja is possible. However, a sentence where a 'do Y:GEN' NP occurs seems to be much more acceptable:

(16) on dozanimalsja matematikoj do golovnoj boli 'He did his mathematics until he got a headache.'

So, some of the valencies inherited from $\mathrm{Z}$ are still possible, though being inseparable ${ }^{6}$ from the do $\mathrm{Y}: \mathrm{GEN}$ valency. ${ }^{7}$

\subsection{Other candidates for consecutives in Russian}

Verbs in $d o-. .$. -sja can form one more type of construction containing an additional argument, namely:

(17) $\mathrm{X} u \mathrm{~W}: \mathrm{GEN} d o+\mathrm{Z}+$ sja do $\mathrm{Y}: \mathrm{GEN}$

Cf.:
(18) On u Petrova dotrenirujetsja do bol'nicy

'He will be coached by Petrov until he'll get into a hospital.'

Similar constructions can be formed by verbs not belonging to the do-... sja-class, too:

(19) $\mathrm{X} u \mathrm{~W}: \mathrm{GEN} \mathrm{Z}$

Cf.:

(20) Petr u novogo načal'nika pokurit v rabočee vremja!

'If Peter smokes during his working hours, the new boss will punish him [somehow].'

(21) - Pročitaj pis'mo na lekcii Sokolova!

- Unego pročitaješ!!

- 'Read the letter at Sokolov's lesson!'

- 'He won't give me any chance!'

It should be emphasized that it is always the main verb that bears the phrasal accent: in constructions like (20) the sentence on the whole has a special phrasal intonation (one of irony, often combined with threat). As can be seen, sentences following the pattern in (19) express a causative situation without specifying a resulting event. Thus, according to the definitions suggested above, they may be treated as consecutives. However, since the circumfix $d o-\ldots$-sja in the main verb is optional, ${ }^{8}$ one may state that the function of a consecutive marker is performed by a specific sentence intonation. (19):

The following sentence type may be considered as a transformation of

(22) W X:DAT Z (with the same intonation as (19)) Cf.:

(23) On tebe pokurit v rabočee vremja!

'He'll [somehow] punish you, if you smoke during your working hours.'

Both (19) and (22) are especially common in colloquial speech.

It is worth mentioning that in these constructions the main participant of $\mathrm{S}$ (denoted by $\mathrm{W}$ ) can also be expressed. It may be referred to as "executor" because $\mathrm{S}$ is always undesirable for $\mathrm{X}$, often being a kind of punishment. 
4.3 Verbs with the prefix $z a-$

Let us consider the following construction:

(24) A $z a-Z \mathrm{X}: \mathrm{ACC}($ do Y:GEN). Cf.:

(25) On zagonjal lošad' (do smerti)

'He rode the horse to death.'

The class of verbs which can be substituted for $\mathrm{Z}$ in this pattern includes imperfective transitive verbs denoting various kinds of physical coercion crucially involving the object in the action. ${ }^{9}$ This construction ${ }^{10}$ also serves to denote the performance of an activity that results in some consequence undesirable for $\mathrm{X}$. The result of a causing event $\mathrm{S}_{j}$ denoted by $z a$-verbs is most commonly 'putting $\mathrm{X}$ out of action, death, breakage, detriment and so on', cf.: muč it' 'torture' - zamučit' 'wear out, torture to death', gnat' 'urge on' - zagnat' 'ride to death', čitat' 'read' - začitat' (do dyr) 'read a book to tatters', etc. This derivational pattern is productive in colloquial speech, as well. In contrast to do-...-sja-consecutives, an agentive participant of $S_{i}$, non-identical with $X$ (the real causer of $S_{j}$ ), is expressed in these constructions.

\section{Consecutives and some adjacent categories}

We will now turn to the problems of distinguishing consecutives from other categories which are similar to the consecutive verbs in some ways.

\subsection{Consecutives and Aktionsarten}

There is no doubt that some of the Russian consecutives are closely related to the system of the so-called Aktionsarten ("modes of action"), which is well elaborated in Russian as well as in other Slavic languages. In particular, in most studies dealing with Russian aspectual categories, do-...-sjaverbs are treated as one of the Aktionsarten, referred to as a "special-resul-

tative Aktionsart with a nuance of excessivity of the action' (special'norezul'tativnyj s ottenkom črezmernosti dejstvija, Maslov 1965:76) or as "final-negative" (final'no-otricatel'nyj, Šeljakin 1983:190). In fact, do-... -sja-verbs appear to be quite similar to those Aktionsarten which denote an excessive (or simply intensive) performance of an action, cf. naest'sja 'have eaten enough', pererabotat' 'work too much', etc.

The question arises as to whether there is any important difference between these Aktionsarten and do-...-sja-verbs. Can these Aktionsarten also be treated as consecutives?

\subsection{Consecutives and perfect}

Another category which seems to be a candidate for inclusion in the consecutive category is perfect. As shown by Maslov (1988: 64-65), the term "perfect" is applied to those verb forms whose meaning "includes two temporal planes: that of precedence, and that of sequence. The situations corresponding to these planes are in some way related as cause and effect." Forms emphasizing the sequence are usually termed "statal perfect", or "resultative" (as in Nedjalkov 1988), whereas those emphasizing the preceding plane, i.e. the cause, are called "actional perfect". The latter type seems to meet conditions (iii-iv) formulated above; that is, it describes a causative situation while reducing the resulting event. A question arises as to whether perfect may be treated as a kind of consecutive.

\subsection{Some relevant criteria for discerning consecutives from other categories}

In this section we shall try to answer the questions formulated in the previous sections (5.1-2).

In order to distinguish do-...-sja-verbs from the above-mentioned Aktionsarten as well as from the perfect, a semantic criterion can be used. A semantic feature shared by both perfect and some Aktionsarten (satives, saturatives, etc.) is the following one: although these categories denote causal chains of events, the resulting event $\left(\mathrm{S}_{\mathrm{j}}\right)$ can be easily predicted from the causing event $\left(\mathrm{S}_{\mathrm{i}}\right)$. In case of perfect $\mathrm{S}_{\mathrm{j}}$ is the most ordinary (trivial) result of $S_{i}$ (e.g. if $S_{i}=$ 'to read a book', $S_{j}=$ 'the book is read'; if $S_{i}=$ 'to build a house', $S_{i}=$ 'the house is built; exists'; etc.). In case of sat(urat)ive verbs like na-kupat'-sja, na-begat'-sja, etc., $\mathrm{S}_{\mathrm{j}}$ may be described as saturation resulting from an excessive (or abundant) performance of the action denoted by $\mathrm{V}_{\mathrm{i}}$. As for consecutives, although the set of possible results is rather limited (various annoyances for $\mathrm{X}$ ) $\mathrm{S}_{\mathrm{j}}$ is not trivial and cannot be unambiguously predicted on the basis of $\mathrm{S}_{\mathrm{i}}$ (if not expressed by a prepositional phrase with $d o$ ). 
Thus, one of the important criteria for determining consecutives may be formulated as follows:

the resulting event is non-trivial and cannot be predicted exactly only on the basis of information about $S_{\mathrm{i}}$.

The importance of the Criterion of Unpredictability can be seen from the fact that it can be used as well for distinguishing causatives from resultatives. Resultatives also denote a causative situation without specifying the cause of the resulting event (see above). However, the character of the cause is quite evident, being, in a way, incorporated in the meaning of resultative: the fact that the house is built (resultative) implies that somebody built the house, the fact that the door is opened implies that somebody has opened it, etc. Similarly, the perfect meaning incorporates some information about the resulting event, so that a sentence like John has bought a car lets us conclude that John is a possessor of a car now. Consecutives and causatives, as opposed to perfect and resultative verbal forms, respectively, give much less information about the consequence/result of a member of the causative situation (although it would be an exaggeration to state that no relevant information at all can be deduced). ${ }^{11}$

So, perfect and resultative share the following interesting semantic feature: they both denote a causative situation without expressing any non-trivial result or cause. 12 This is why perfect and resultative can be regarded as "degenerate" consecutive and causative, respectively.

This discussion on the various categories that denote a causative situation but differ in the degree of reduction and/or triviality of either cause or result is summarized in Table 1 . The following degrees of reduction of expression of an event seem to be relevant for this preliminary presentation:

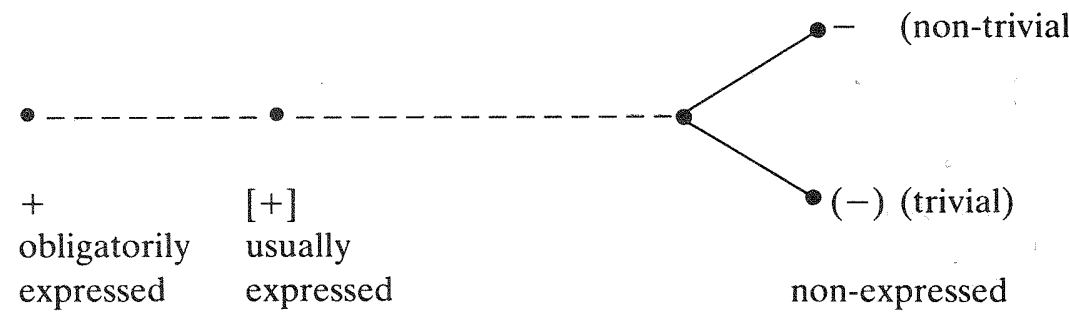

A table representing the basic asymmetric combinations of these features would look as follows:
Table 1

\begin{tabular}{l|l|l|l}
\hline & $\begin{array}{l}\text { causing } \\
\text { event }\end{array}$ & $\begin{array}{l}\text { caused } \\
\text { event }\end{array}$ & verb type \\
\hline $\begin{array}{l}\text { result- } \\
\text { oriented }\end{array}$ & {$[+]$} & + & causatives as in Nivkh $($ fn. 5) \\
categories & -- & + & ordinary causatives \\
\hline & $(-)$ & + & resultatives \\
cause- & + & {$[+]$} & verbs in $-k$ śséha in Andoke \\
criented & + & - & consecutives \\
\hline
\end{tabular}

Another criterion for distinguishing between consecutives and adjacent categories is based on syntactic changes which an initial clause undergoes through consecutivization. The main verb is subordinated to the predicate CAUSE, and a new argument appears in the sentence, namely Sequence. As we mentioned above, this argument is most commonly optional, however, it becomes obligatory with imperfective do-...-sja-verbs; cf. the following incorrect sentence:

(26) *on dotrenirovyvalsja he train:CONS:IMPFV:PAST

This example becomes correct, only if the Sequence is expressed:

(27) on [neskol'ko raz] dotrenirovyvalsja do travmy '[several times] he trained until he got a trauma'

This is not the only modification of the syntactic structure which accompanies consecutivization. As indicated above (Sec.4.1), the Sequence valency interacts in a rather complicated way with the inherited valencies of the initial (non-consecutive) verb (roughly speaking, they are prohibited if the Sequence is omitted).

Thus, consecutivization presupposes a considerable rearrangement of the syntactic structure, in some respects similar to causativization (which also provides a new valency) or other kinds of syntactic derivation. On the other hand, most of the Aktionsarten mentioned in 5.1 as well as perfect do not so crucially influence the syntactic properties of the underlying verb. 


\section{Some parameters for a typological classification of consecutives}

\subsection{Semantics}

Both do-...-sja-verbs and $z a$-verbs denote an event $\left(\mathrm{S}_{i}\right)$ that causes a negative result, i.e. something undesirable for the main participant of $S_{i}$. Therefore, these verbs may be called "maleconsecutives". It is quite probable that in some languages "beneconsecutives" occur.

\subsection{Diathesis types}

At least the following two types can be distinguished as to whether the subject of the resulting event $S_{j}$ is coreferential with either subject or object of the causing event $S_{i}$.

In the former case, the term "subject consecutive" may be used. Thus, do-...-sja-verbs are subject consecutives:

(28) Petr dokurilsja do golovnoj boli. $=$ [Peter smoked much] Caus [Peter got headache]

On the other hand, if $S_{j}$-subject is coreferential with the $S_{i}$-object, the term "object consecutive" can be used, as in the case of Russian $z a$-verbs:

(29) Petr zagnal lošad' do smerti $=[$ Peter overdrove the horse] CAUS [the horse died].

\section{Conclusion}

Our goal in this paper has been to simply sketch some of the relevant parameters in the description of consecutives. A more detailed typological study of consecutives should be based on data from at least a number of languages. In fact, do-...-sja -consecutives similar to the Russian type occur in some other Slavic languages, for instance, in Ukrainian (Il'in 1953: 47) and in Polish (Puškar 1963: 32-33). ${ }^{13}$

Unfortunately, we have not had the opportunity to study examples of consecutives in other languages. We hypothesize that consecutives may be found in other languages, especially in those languages that have a complicated system of Aktionsarten. The present paper can be considered as a request for typologically relevant data. We would be greatly obliged if typologists and experts in various languages would provide us with exam- ples of morphological (synthetic) or periphrastic consecutives from the languages of their competence.

\section{NOTES}

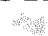

1. It is noted, for instance, by Talmy (1976), who indicates that $S_{i}$ appears in a causative sentence as a ground whereas $S_{j}$ is a figure.

2. See, for instance, Isačenko (1960: 250; Švedova et al. 1980: 386); Znamenskaja (1958: 17 19); Golovin (1959: 145-146); Bogusławski (1963: 73); Rudolfová (1973: 24-25); etc. These verbs are dealt with in a paper by Rojzenzon (1959) containing many interesting and insightful observations. See also a recent monograph by Janda (1986: 181-188).

3. To simplify the formula, we do not touch upon the problem of distinguishing between the presuppositional and assertive components of the definition

4. It is worth noting that the argument referred to as do Y:GEN is most commonly optional. Only with imperfective $d o-\ldots-$-sja-verbs is it obligatory (see Mel'čuk 1987; Rudolfová 1973: 25).

5. It should be mentioned that not all languages display the same degree of reduction of the causing event. For instance, as has been indicated in the sketch on Nivkh (Gilyak) causatives by Nedjalkov, Otaina, and Xolodovič (1969: 186; Engl. translation 1988: 33), the Nivkh morphological causative in -gu- is usually accompanied by a phrase indicating the means of causation, as in the following example:

if, plark krasir, valvala-gu-d'

he his shirt dye:Ger be black-CAus-Fin

'By dyeing his shirt, he made (it) black.'

In this respect, the Nivkh CC's appear to be a more exact "looking-glass copy" of Russian CsC's.

6. We use this term in the sense of Apresjan (1974: 152)

7. We have mentioned only one problem concerned with a full lexicographic description of Russian consecutives in do-...-sja. A more detailed analysis of other problems, such as the transformations of syntactic properties of the underlying verb $\mathrm{Z}$ and the lexicalization of some do-...-sja-verbs (cf. doigrat'sja 'to get into trouble', lit. 'play:cons'; doprygat'sja 'id.', lit. 'jump:Cons'; etc.) could be the subject of a separate investigation.

8. Incidentally, verbs with the prefix po- are very common in such sentences. The future tense seems to be most appropriate for these constructions (although the past tense is also possible).

9. It should be stressed that not all imperfective transitives may occur in this construction; for instance, it is impossible for verbs denoting a process of creation such as stroit' 'build'.

10. See Švedova et al. (eds.) (1980: 360); Golovin (1964: 56-57); Janda (1986: 103-112).

11. In particular, consecutives in do-...-sja incorporate the meaning ' $\mathrm{S}$ is unfavorable' whereas causatives may contain some information about the character of causation and, hence, about the causing event. Cf. the opposition of direct (= causation by direct man- 
ipulation) and indirect ( $=$ causation by asking, persuasion, etc.) causatives; factitives vs. permissives; etc.

12. For the notion of triviality, see Kozinskij (1988: 499).

13. However, this category is not attested in all Slavic languages: there are no consecutives in Czech, Slovak, etc.

\section{REF RENCES}

Apresjan, Jurij D. 1974. Leksičeskaja semantika. Moskow: Nauka.

Boguslawski, Andržej. 1963. Prefiksacja czasownikowa we wspólczesnym języku rosyjskim. Wrocław - Warszawa - Kraków: Zakład narodowy imenia Ossolińskich Polska Akademia Nauk.

Golovin, B.N. 1959. "Slovoobrazovatel'naja tipologija russkix pristavočnyx glagolov". In: Vinogradov, V.V. (ed.), Slavjanskoe jazykoznanie, 139-148. Moskva: Izd-vo AN SSSR.

Golovin, B.N. 1964. "Slovoobrazovatelnye tipy glagolov s pristavkoj za-". Učenye zapiski Gor'kovskogo gosudarstvennogo universiteta. Serija lingvističeskaja 68: 47-69. Il'ïn, Vasil' S. 1953. Prefiksi v sučasnij ukrains'kij movi. Kiev: Akad. nauk Ukr. RSR. Isačenko, Aleksandr V. 1960. Grammatičeskij stroj russkogo jazyka v sopostavlenii so slovackim. T.II. Bratislava: Slovackaja akad. nauk.

Janda, Laura A. 1986. A semantic analysis of the Russian verbal prefixes za-, pere-, do-, and ot- (Slawistische Beiträge 192.). München: Sagner.

Kozinskij, Isaac S. 1988. "Resultative: Results and Discussion". In Nedjalkov (ed.) 1988, 497-525.

Landaburu, Jon. 1979. La langue des Andoke (Amazonie colombienne). Grammaire. Paris: SELAF.

Maslov, Ju.S. 1976. "Sistema osnovnyx ponjatij i terminov slavjanskoj aspektologii”. In Maslov, Ju.S.; and Fedorov, A.V. (eds) Voprosy obščego jazykoznanija, 53-80. Leningrad: Izd-vo Leningradskogo universiteta.

Maslov, Jurij S. 1988. "Resultative, perfect, and aspect". In Nedjalkov (ed.) 1988, 6385.

Mel'čuk, Igor' A. 1987. "Un affixe dérivationnel et un phrasème syntaxique du russe moderne: Essai de description formelle". Revue des études slaves 59: 631-648.

Nedjalkov, Vladimir P.; Otaina, Galina A.; and Xolodovič, Aleksandr A.. 1969. "Morfologičeskij i leksičeskij kauzativy v nivxskom jazyke". In Xolodovič (ed.) 1969, 179 199.

Nedjalkov, Vladimir P.; and Sil'nickij, Georgij G. 1969a. "Tipologija kauzativnyx konstrukcij”. In Xolodovič (ed.), 5-19.

Nedjalkov, Vladimir P.; and Sil'nickij, Georgij G. 1969b. "Tipologija morfologičeskogo i leksičeskogo kauzativov". In Xolodovič (ed.), 20-50.

Nedjalkov, Vladimir P. (ed.) 1988. The Typology of Resultative Constructions. Amsterdam - Philadelphia: John Benjamins.

Puškar, M.A. 1963. "Funkcii dijeslivnoho prefiksa do- u čes'kij movi". Pytann'a slov'ans'kogo movoznavstva 9:18-35. L'viv.
Rojzenzon, Leonid I. 1959. "Stilističeskie nabludenija nad vozvratnymi glagolami s pristavkoj do-v sovre Imennom russkom jazyke". In Rojzenzon, L. I. (ed.), Uzbekskij gos. universitet imeni Ališera Navoi. Kafedra russkogo jazyka. Kratkie soobščenija, 24-33. Samarkand: Izd-vo Uzbekskogo gos. universiteta.

Rudolfová, L. 1973. "Lexikálně sémantická charakteristika ruských reflexívních sloves s předponou do-". Československá rusistika XVIII: $21-26$.

Šljakin, Mixail A. 1983. Kategorija vida i sposoby dejstvija russkogo glagola (Teoretičeskie osnovy). Tallinn: Valgus.

Švedova, N.Ju. et al. (eds) 1980. Russkaja grammatika. T.II. Moskva: Nauka.

Thlmy, Leonard. 1976. "Semantic causative types". In Shibatani, M. (ed.) Syntax and Semantics 6. The Grammar of Causative Constructions, 43-116. New York: Academic Press.

Xolodovič, Aleksandr A. (ed.) 1969. Tipologija kauzativnyx konstrukcij. Morfologičeskij kauzativ. Leningrad: Nauka.

Znamenskaja, A.V. 1958. "Prefiksal'no-suffiksal'noe obrazovanie vozvratnyx glagolov". Učenye zapiski Borisoglebskogo gosudarstvennogo pedagogičeskogo in-ta 5: $3-42$. 